\title{
Dopamine Differentially Modulates the Excitability of Striatal Neurons of the Direct and Indirect Pathways in Lamprey
}

\author{
Jesper Ericsson, ${ }^{1 \star}$ Marcus Stephenson-Jones, ${ }^{1 \star}$ Juan Pérez-Fernández, ${ }^{2}$ Brita Robertson, ${ }^{1}$ Gilad Silberberg, ${ }^{1}$ \\ and Sten Grillner ${ }^{1}$ \\ ${ }^{1}$ Department of Neuroscience, Nobel Institute for Neurophysiology, Karolinska Institute, SE-171 77 Stockholm, Sweden, and 2Department of Functional \\ Biology and Health Sciences, Faculty of Biology, Neurolam Group, University of Vigo, 36310 Vigo, Spain
}

The functions of the basal ganglia are critically dependent on dopamine. In mammals, dopamine differentially modulates the excitability of the direct and indirect striatal projection neurons, and these populations selectively express dopamine $\mathrm{D}_{1}$ and $\mathrm{D}_{2}$ receptors, respectively. Although the detailed organization of the basal ganglia is conserved throughout the vertebrate phylum, it was unknown whether the differential dopamine modulation of the direct and indirect pathways is present in non-mammalian species. We aim here to determine whether the receptor expression and opposing dopaminergic modulation of the direct and indirect pathways is present in one of the phylogenetically oldest vertebrates, the river lamprey. Using in situ hybridization and patch-clamp recordings, we show that $\mathrm{D}_{1}$ receptors are almost exclusively expressed in the striatal neurons projecting directly to the homolog of the substantia nigra pars reticulata. In addition, the majority of striatal neurons projecting to the homolog of the globus pallidus interna/globus pallidus externa express $\mathrm{D}_{1}$ or $\mathrm{D}_{2}$ receptors. As in mammals, application of dopamine receptor agonists differentially modulates the excitability of these neurons, increasing the excitability of the $\mathrm{D}_{1}$-expressing neurons and decreasing the excitability of $\mathrm{D}_{2}$-expressing neurons. Our results suggest that the segregated expression of the $\mathrm{D}_{1}$ and $\mathrm{D}_{2}$ receptors in the direct and indirect striatal projection neurons has been conserved across the vertebrate phylum. Because dopamine receptor agonists differentially modulate these pathways, increasing the excitability of the direct pathway and decreasing the excitability of the indirect pathway, this organization may be conserved as a mechanism that biases the networks toward action selection.

\section{Introduction}

The basal ganglia are a group of subcortical nuclei that are conserved throughout the vertebrate phylum and play a critical role in action selection and procedural learning (Redgrave et al., 1999; Stephenson-Jones et al., 2011, 2012). The functions of these nuclei are critically dependent on dopamine, released from neurons in the substantia nigra pars compacta $(\mathrm{SNc})$ and ventral tegmental area (VTA). In all vertebrates studied, loss of this dopaminergic innervation leads to parkinsonian symptoms, involving a combination of bradykinesia, rigidity, and postural instability (Barbeau et al., 1985; Albin et al., 1989; Pollard et al., 1992; Yanai et al., 1995; Thompson et al., 2008). This suggests that, as with the

\footnotetext{
Received Dec. 25, 2012; revised March 23, 2013; accepted March 28, 2013.

Author contributions: J.E., M.S.-J., J.P.-F., B.R., G.S., and S.G. designed research; J.E., M.S.-J., and J.P.-F. performed research; J.E., M.S.-J., and J.P.-F. analyzed data; J.E. and M.S.-J. wrote the paper.

This study was supported by the European Union FP7 "Lampetra" 216100, FP7 "Select-and-Act" 201716, Swedish Research Council Grants VR-M 3026 and VR-NT 621-2007-6049, Karolinska Institute research funds, the European Union Cortex Training Program, and Ministry of Science and Innovation/Federation for Rare Diseases Grant BFU2009-13369.

*J.E. and M.S.-J. contributed equally to this work.

Correspondence should be addressed to Prof. Sten Grillner, Department of Neuroscience, Nobel Institute for Neurophysiology, Karolinska Institutet, SE-171 77 Stockholm, Sweden. E-mail: sten.grillner@ki.se

DOI:10.1523/JNEUROSCI.5881-12.2013

Copyright $\odot 2013$ the authors $\quad 0270-6474 / 13 / 338045-10 \$ 15.00 / 0$
}

intrinsic basal ganglia organization, the mechanisms by which dopamine modulates these nuclei may also be conserved.

In mammals, dopamine differentially modulates the excitability of the striatal projection neurons by increasing the excitability of spiny projection neurons (SPNs) that project directly to the output layer of the basal ganglia, the globus pallidus interna (GPi)/substantia nigra pars reticulata ( $\mathrm{SNr}$ ), and decreasing the excitability of SPNs that project indirectly to these nuclei via the globus pallidus externa (GPe) (Hernández-López et al., 1997; Surmeier et al., 2007). This dichotomous effect is attributable to a differential expression of dopamine receptors on the two types of projection neurons: (1) directly projecting SPNs express the dopamine $\mathrm{D}_{1}$ receptor, and (2) indirectly projecting SPNs express the $\mathrm{D}_{2}$ receptor (Gerfen and Surmeier, 2011).

Elements of this neuromodulatory organization may be conserved, because the striatum of non-mammalian vertebrates (lamprey, amphibians, reptiles, and birds) also receives a large dopaminergic projection from the homolog of the SNc/VTA and express $\mathrm{D}_{1}$ and $\mathrm{D}_{2}$ receptors (Reiner et al., 1998; Chu et al., 2001; Pombal et al., 2007; Robertson et al., 2012). Furthermore, in turtles and birds, dopamine excites striatal neurons that express $D_{1}$ receptors and inhibits neurons that express $D_{2}$ receptors (Ding and Perkel, 2002; Barral et al., 2010). Despite this, in nonmammalian vertebrates, it is unknown whether the neurons associated with the direct and indirect pathway selectively express 
$D_{1}$ and $D_{2}$ receptors, respectively, or whether the excitability of these neurons is differentially modulated by dopamine.

Our aim here is to use the lamprey, one of the phylogenetically oldest vertebrates, to determine whether the differential dopaminergic modulation of the direct and indirect pathways is conserved across the vertebrate phylum. Using anatomical and electrophysiological techniques, we show that $\mathrm{D}_{1}$ or $\mathrm{D}_{2}$ receptors are expressed in the direct and indirect lamprey striatal projection neurons, respectively. Furthermore, as in mammals, application of dopamine receptor agonists differentially modulates the excitability of these neurons, increasing the excitability of the $\mathrm{D}_{1}$-expressing neurons and decreasing the excitability of $\mathrm{D}_{2}$ expressing neurons. Our results suggest that the differential dopaminergic modulation of the direct and indirect pathways was present at the dawn of vertebrate evolution and part of the blueprint for the vertebrate basal ganglia. The conservation of this circuitry may explain why all vertebrates exhibit parkinsonian symptoms after dopamine depletion.

\section{Materials and Methods}

Experiments were performed on a total of 49 adult river lampreys (Lampetra fluviatilis) of either sex. The experimental procedures were approved by the local ethical committee (Northern Stockholm Animal Review Board) and were in accordance with National Institutes of Health Guide for the Care and Use of Laboratory Animals (1996 revision). Every effort was made to minimize animal suffering and to reduce the number of animals used during the study.

Slice preparation and patch-clamp experiments. Acute brain slices were prepared by dissecting out brains in ice-cold artificial CSF (aCSF) with the following composition (in $\mathrm{mM}$ ): $125 \mathrm{NaCl}, 2.5 \mathrm{KCl}, 1 \mathrm{MgCl}_{2}, 1.25$ $\mathrm{NaH}_{2} \mathrm{PO}_{4}, 2 \mathrm{CaCl}_{2}, 25 \mathrm{NaHCO}_{3}$, and 8-10 glucose. The aCSF was oxygenated continuously with $95 \% \mathrm{O}_{2}$ and $5 \% \mathrm{CO}_{2}$, and the $\mathrm{pH}(7.4)$ was routinely checked. To facilitate the cutting of brain slices on a microtome (Microm HM 650V; Thermo Fisher Scientific), preheated liquid agar (Sigma-Aldrich) dissolved in water at a concentration of $4 \%$ was prepared. The agar block containing the brain was then glued to a metal plate and transferred to ice-cold aCSF in the microtome chamber. Coronal brain slices of 350-400 $\mu \mathrm{m}$ were cut at the level of the striatum and allowed to recover for at least $1 \mathrm{~h}$ in cold aCSF, before being transferred to a submerged recording chamber. Perfusion of slices was performed with aCSF at $6-8^{\circ} \mathrm{C}$ using a Peltier cooling system (ELFA).

Whole-cell somatic current-clamp recordings were made from labeled and unlabeled neurons with patch pipettes made from borosilicate glass microcapillaries (Hilgenberg) using a horizontal puller (model P-97; Sutter Instruments). Recording pipettes (7-12 M $\Omega$ ) were filled with intracellular solution of the following composition (in $\mathrm{mM}$ ): 105 K-gluconate, $30 \mathrm{KCl}, 10 \mathrm{HEPES}, 4 \mathrm{Mg}$-ATP, $0.3 \mathrm{Na}-\mathrm{GTP}$, and 10 phosphocreatine sodium salt (265-275 mOsm osmolarity). Bridge balance and pipette capacitance compensation were adjusted for on the Axoclamp 2B amplifier (Molecular Devices). Neurons were visualized with infrared differential interference contrast optics (Olympus BX51WI) and retrogradely labeled neurons (Rhodamine Red-dextran or Alexa Fluor 488-dextran) were identified by switching from infrared to epifluorescence mode. Data collection and analysis were performed with ITC-18 (HEKA) and Igor software (version 6.03; Wavemetrics).

Passive and active electrophysiological properties were recorded in current-clamp mode by negative and positive current injections. We injected 10 consecutive step currents ( $1 \mathrm{~s}$ duration) of increasing amplitudes to evoke action potentials (APs). The amplitudes of the current injections were scaled to the input resistance of individual neurons so that the second or third injection evoked one AP on average, which was used to extract single AP parameters. The current-voltage relationships were also used to analyze current-frequency relationships and the input resistance of cells. In the same experiment, step currents were kept constant after the initial scaling to compare the number of APs and its parameters before, during, and after application of drugs. This was performed from a depolarized $(-55$ to $-65 \mathrm{mV}$ ) or hyperpolarized
( -80 to $-90 \mathrm{mV}$ ) baseline, and the current clamp was monitored and adjusted for to compensate for any depolarization or hyperpolarization of the membrane potential initiated by drug application to keep the voltage baseline close to constant. The effects of drugs on the excitability of neurons were assessed by comparing the number of APs evoked at near-rheobase current injections. In cells that also exhibited postinhibitory rebound (PIR) spikes, the effect of drugs was assessed by comparing the total number of PIR spikes in response to $8-10$ consecutive hyperpolarizations from $-100 \mathrm{mV}$ to baseline.

Drug application. Pharmacological agents were bath applied through the perfusion system. The dopamine $D_{1}$ receptor agonist SKF 81297 [( \pm )-6-chloro-2,3,4,5-tetrahydro-1-phenyl-1 H-3-benzazepine hydrobromide; Tocris Bioscience] was prepared freshly and dissolved to $10 \mu \mathrm{M}$ (up to $20 \mu \mathrm{M}$ in initial experiments) in aCSF. The dopamine $\mathrm{D}_{2}$ receptor agonist TNPA $[R(-)-2,10,11$-trihydroxy- $N$-propyl-noraporphine 123 hydrobromide hydrate; Sigma-Aldrich] was prepared freshly and first dissolved to $100 \mathrm{~mm}$ in $99.5 \%$ ethanol before dilution to $100 \mu \mathrm{M}$ in aCSF. In sequential drug applications, the quantification of effects of the second drug was compared with the latter part of the wash period before application. The mixed population of striatopallidal neurons were divided into two groups (indirect/direct) by evaluating whether (1) $\mathrm{D}_{2}$ activation affected excitability and (2) $\mathrm{D}_{1}$ activation affected excitability. This grouping was based on the in situ hybridization results $\left(\sim 50 \% \mathrm{D}_{2}\right.$ or $\mathrm{D}_{1}$ receptor-expressing neurons) and that $\mathrm{D}_{2}$ activation had a potent effect in responsive neurons (Robertson et al., 2012). In the general investigation of SKF 81297 activation (see Fig. 4) and TNPA activation (see Fig. 5), striatonigral, striatopallidal, and unlabeled neurons that responded to either drug were included in the analysis.

Statistical analyses. To test whether the data were normally distributed, datasets were investigated with Shapiro-Wilk normality tests. Statistical analyses were made with two-tailed paired $t$ tests for all normally distributed data, and the nonparametric Wilcoxon's matched-pairs signedranks test was used for datasets that were not normally distributed. Results are presented as mean \pm SEM.

Retrograde tracing. Lampreys were deeply anesthetized in MS-222 (100 $\mathrm{mg} / \mathrm{L}$; Sigma-Aldrich) in ice-cooled oxygenated HEPES-buffered physiological solution (in mM: $138 \mathrm{NaCl}, 2.1 \mathrm{KCl}, 1.8 \mathrm{CaCl}_{2}, 1.2 \mathrm{MgCl}_{2}, 4$ glucose, and 2 HEPES, pH 7.4). All injections were made with glass (borosilicate, $1.5 \mathrm{~mm}$ outer diameter, $1.17 \mathrm{~mm}$ inner diameter) micropipettes, with a tip diameter of $10-20 \mu \mathrm{m}$. The micropipettes were fixed in a holder, which was attached to an air supply and a Narishige micromanipulator. Fifty to $200 \mathrm{nl}$ of $20 \%$ Neurobiotin (in distilled water containing fast green to aid visualization of the spread of the injection; Vector Laboratories) was pressure injected unilaterally into either the homolog of the SNr located in the caudal mesencephalon or the dorsal pallidum (homolog of the mixed GPi/GPe) in the area ventrolateral to the eminentia thalami. After the injections, the animals were returned to their aquarium for $16-20 \mathrm{~h}$.

Probes for in situ hybridization. Templates for in vitro transcription were prepared by PCR amplification. For the $\mathrm{D}_{2}$ receptor probe, a $660 \mathrm{bp}$ fragment was obtained using $5^{\prime}$-TGCTCATATGCCTCATCGTC-3' forward and 5'-TCAAGCTTTGCACAATCGTC-3' reverse primers (Robertson et al., 2012), and for the $\mathrm{D}_{1}$ receptor probe, a $549 \mathrm{bp}$ fragment was obtained using $5^{\prime}$-CTGTCCGTGCTCATCTCCTTTAT-3' forward and 5'-CCAGCCGAACCATACGAAG-3' reverse primers (GenBank accession number AJ005434.1p). The amplified cDNA fragments were cloned into a pCRII-TOPO vector (Invitrogen), cleaned, and confirmed by nucleotide sequencing (KIGene, Core Facility at Karolinska Institute, Stockholm, Sweden). Linearized plasmids ( $1 \mu \mathrm{g})$ were used to synthesize digoxigenin (DIG)-labeled riboprobes. In vitro transcription was performed using the DIG RNA Labeling Mix (Roche Diagnostics) according to the instructions of the manufacturer. The transcripts were purified using NucAway spin columns (Applied Biosystems). Sense probes were used as negative controls.

In situ hybridization. The Neurobiotin-injected animals were deeply anesthetized in MS-222 diluted in fresh water and killed by decapitation. Brains were quickly removed and fixed in $4 \%$ paraformaldehyde in 0.01 M PBS overnight at $4^{\circ} \mathrm{C}$. Afterward, they were cryoprotected in $20 \%$ sucrose in $0.01 \mathrm{M}$ PBS overnight, and $20-\mu \mathrm{m}$-thick serial, transverse cry- 
ostat sections were obtained and immediately used for in situ hybridization. The sections were left at room temperature for $30 \mathrm{~min}$, washed in $0.01 \mathrm{M}$ PBS, acetylated in $0.25 \%$ acetic anhydride in $0.1 \mathrm{M}$ triethanolamine, $\mathrm{pH} 8.0$, for $5 \mathrm{~min}$, washed in $0.01 \mathrm{M} \mathrm{PBS}$, and prehybridized ( $50 \%$ formamide, $5 \times$ SSC, pH 7.0, $5 \times$ Denhardt's solution, $500 \mu \mathrm{g} / \mathrm{ml}$ salmon sperm DNA, and $250 \mu \mathrm{g} / \mathrm{ml}$ yeast RNA) for $2-4 \mathrm{~h}$ at $60^{\circ} \mathrm{C}$. DIG-labeled $\mathrm{D}_{1}$ and $\mathrm{D}_{2}$ riboprobes were prepared and added to the hybridization solution to a final concentration of $500 \mathrm{ng} / \mathrm{ml}$, and parallel series were hybridized overnight at $60^{\circ} \mathrm{C}$. An RNase treatment $(20 \mu \mathrm{g} / \mathrm{ml}$ in $2 \times \mathrm{SSC})$ was performed for $30 \mathrm{~min}$ at $37^{\circ} \mathrm{C}$ after stringent washes in SSC (Applied Biosystems). After additional washes in maleic acid buffer (MABT), pH 7.5 , the sections were incubated overnight at $4^{\circ} \mathrm{C}$ in anti-DIG Fab fragments conjugated with alkaline phosphatase (1:2000; Roche Diagnostics) in $10 \%$ heat inactivated normal goat serum (Vector Laboratories). Several washes in MABT were performed, and the alkaline phosphatase reaction was visualized using NBT/BCIP substrate (Roche Diagnostics) in staining buffer ( $0.1 \mathrm{M}$ Tris buffer, $\mathrm{pH} 9.5$, containing 100 $\mathrm{mm} \mathrm{NaCl}$ and $5 \mathrm{~mm}$ levamisole). The staining process was stopped with washes in PBS. Those sections that had been subjected to retrograde tracing with Neurobiotin were subsequently incubated with streptavidin conjugated to Cy3 (1:1000; Jackson ImmunoResearch). Sections were coverslipped with glycerol containing 2.5\% 1,4diazabicyclo-[2.2.2] octane (Sigma-Aldrich).

Colocalization of the Neurobiotin retrograde labeling with the in situ hybridization signal for dopamine $\mathrm{D}_{1}$ and $\mathrm{D}_{2}$ receptors was analyzed in 17 animals $\left(\mathrm{SNr}-\mathrm{D}_{2}, n=4 ; \mathrm{SNr}-\mathrm{D}_{2}, n=5 ; \mathrm{DP}-\mathrm{D}_{2}, n=6 ; \mathrm{DP}-\mathrm{D}_{1}, n=\right.$ 2). In each case, at least 10 sections $(20 \mu \mathrm{m})$ were counted, each section contained between 5 and 20 cells, and sections that were analyzed were at least $20 \mu \mathrm{m}$ apart to ensure that the same cell was not counted twice.

\section{Results}

\section{Striatonigral neurons selectively express $D_{1}$ receptors}

In lamprey, two genes have been identified that encode for homologs of the mammalian dopamine $\mathrm{D}_{1}$ and $\mathrm{D}_{2}$ receptors. The mRNA for each of these receptors is expressed in a subpopulation of striatal neurons (Pombal et al., 2007; Robertson et al., 2012). In lamprey, as in mammals, there are two subpopulations of striatal projection neurons: (1) one that expresses substance $\mathrm{P}$ and projects directly to the GABAergic output neurons in the $\mathrm{SNr}$ and $\mathrm{GPi}$, and (2) another that expresses enkephalin and projects to the homolog of the GPe (Stephenson-Jones et al., 2011, 2012).

To determine whether dopamine $\mathrm{D}_{1}$ and $\mathrm{D}_{2}$ receptors are differentially expressed in the striatal neurons associated with the direct and indirect pathways and to determine how dopamine modulates the excitability of these projection neurons, we first analyzed the dopamine receptor expression in striatal neurons projecting to the homolog of the SNr. Retrograde labeling from the $\mathrm{SNr}$ combined with in situ hybridization revealed that, as in mammals, the majority of striatal neurons projecting to the $\mathrm{SNr}$ colocalize with the in situ hybridization signal for the $\mathrm{D}_{1}$ receptor (Fig. $1 A-D ; 66.2 \pm 13.8 \%, n=5$ ). In contrast, very few of the retrogradely labeled neurons colocalize with the in situ hybridization signal for the $\mathrm{D}_{2}$ receptor (Fig. $1 E-H ; 4.2 \pm 5.9 \%, n=4$ ). Note the marked difference between $\mathrm{D}_{1}$ - and $\mathrm{D}_{2}$-expressing striatonigral neurons in the histograms in Figure $1, D$ and $H$, respectively. These results thus suggest that the majority of striatonigral neurons express dopamine $\mathrm{D}_{1}$ receptors. In addition, a small subpopulation $(<5 \%)$ of striatonigral neurons may also coexpress dopamine $\mathrm{D}_{1}$ and $\mathrm{D}_{2}$ receptors.

In mammals, birds, and reptiles, dopamine $\mathrm{D}_{1}$ receptor agonists have been shown to preferentially enhance excitability, whereas $D_{2}$ receptor agonists mainly reduce excitability (Hernández-López et al., 1997, 2000; Ding and Perkel, 2002; Barral et al., 2010). To investigate whether both dopamine receptor agonists influenced the excitability of the retrogradely labeled striatonigral neurons, we sequentially applied $\mathrm{D}_{1}$ and $\mathrm{D}_{2}$ agonists in whole-cell patch-clamp experiments. Figure $1 I$ shows a striatonigral neuron in which application of the $\mathrm{D}_{1}$ agonist SKF $81297(10 \mu \mathrm{M}$, red trace and application time bar) excited the neuron. Wash of the $\mathrm{D}_{1}$ agonist (Fig. $1 I$, black trace) decreased the number of evoked spikes toward baseline, although the frequency was not fully reversed. Subsequent application of the $\mathrm{D}_{2}$ agonist TNPA $(100 \mu \mathrm{M})$ in the same neuron did not affect the evoked spike activity (Fig. $1 I$, blue trace and time bar). This neuron thus only responded to $D_{1}$ receptor activation. Application of the $D_{1}$ receptor agonist SKF 81297 increased the excitability of 7 of 10 striatonigral neurons ( $p<0.05$, Wilcoxon's signed-ranks test, $n=10$; Fig. $1 J)$, as seen by the increased number of evoked spikes to the same positive current injection compared with the frequency before drug application, with an average increase in firing of $40 \pm$ $18 \%$. One neuron did not respond at all to $\mathrm{D}_{1}$ activation. $\mathrm{A}_{2}$ receptor agonist, TNPA, was then sequentially applied to six of the striatonigral neurons that responded to SKF 81297; five of these were unresponsive (Fig. $1 K ; p=0.36$, $t$ test) to $\mathrm{D}_{2}$ receptor activation (Fig. $1 J)$, and one neuron responded with a decrease in excitability, suggesting that this neuron may coexpress both $\mathrm{D}_{1}$ and $\mathrm{D}_{2}$ receptors. Figure $1 I$ shows a striatonigral neuron in which application of the $\mathrm{D}_{1}$ agonist SKF 81297 (10 $\mu \mathrm{M}$, red trace and application time bar) excited the neuron. Wash of the $\mathrm{D}_{1}$ agonist (Fig. 1I, black trace) decreased the number of evoked spikes toward baseline, although the frequency was not fully reversed. Subsequent application of the $\mathrm{D}_{2}$ agonist TNPA $(100 \mu \mathrm{M})$ to the same neuron did not affect the evoked spiking (Fig. 1I, blue trace and time bar). This neuron thus only responded to $\mathrm{D}_{1}$ receptor activation.

These results show that the majority of striatal neurons that project directly to the output nuclei of the basal ganglia selectively express dopamine $D_{1}$ receptors, which when activated increase the excitability of these neurons. In addition, a small population of striatonigral neurons may coexpress $\mathrm{D}_{2}$ receptors.

\section{A subpopulation of striatal neurons projecting to the mixed GPi/GPe nucleus expresses $D_{2}$ receptors that reduce excitability during activation}

In lamprey, as in birds and reptiles, the homologs of the GPi and GPe are intermingled in one nucleus, referred to as the dorsal pallidum (Reiner et al., 1998; Stephenson-Jones et al., 2011). Accordingly, the lamprey striatopallidal projection contains two different types of projection neurons: (1) one that expresses enkephalin and that preferentially targets pallidal output neurons of the indirect pathway (GPe) and (2) another that expresses substance $\mathrm{P}$ and contacts pallidal projection neurons of the direct pathway (GPi) (Stephenson-Jones et al., 2011). In mammals, these separate subpopulations of direct and indirect SPNs express $D_{1}$ and $D_{2}$ receptors, respectively. If this organization is conserved, then separate subpopulations of striatal neurons projecting to the dorsal pallidum should express either $D_{1}$ or $D_{2}$ receptors. In line with this, just less than half of the striatal neurons, retrogradely labeled from the dorsal pallidum, colocalized with the in situ hybridization signal for the $\mathrm{D}_{2}$ receptor (Fig. $2 A-D ; 47.1 \pm 12.8 \%, n=6)$.

To investigate whether $D_{1}$ and $D_{2}$ receptor agonists influenced the excitability of the retrogradely labeled striatopallidal neurons, we sequentially applied $\mathrm{D}_{1}$ and $\mathrm{D}_{2}$ agonists in whole-cell patch-clamp experiments. Figure $2 E$ shows a retrogradely labeled striatopallidal neuron with evoked APs in response to nearrheobase positive current injections from a depolarized baseline. Application of SKF 81297 (10 $\mu \mathrm{M}$, red trace and time bar) had no effect on the frequency of evoked spikes, whereas subsequent application of TNPA (100 $\mu \mathrm{M}$, blue trace and time bar) potently reduced 

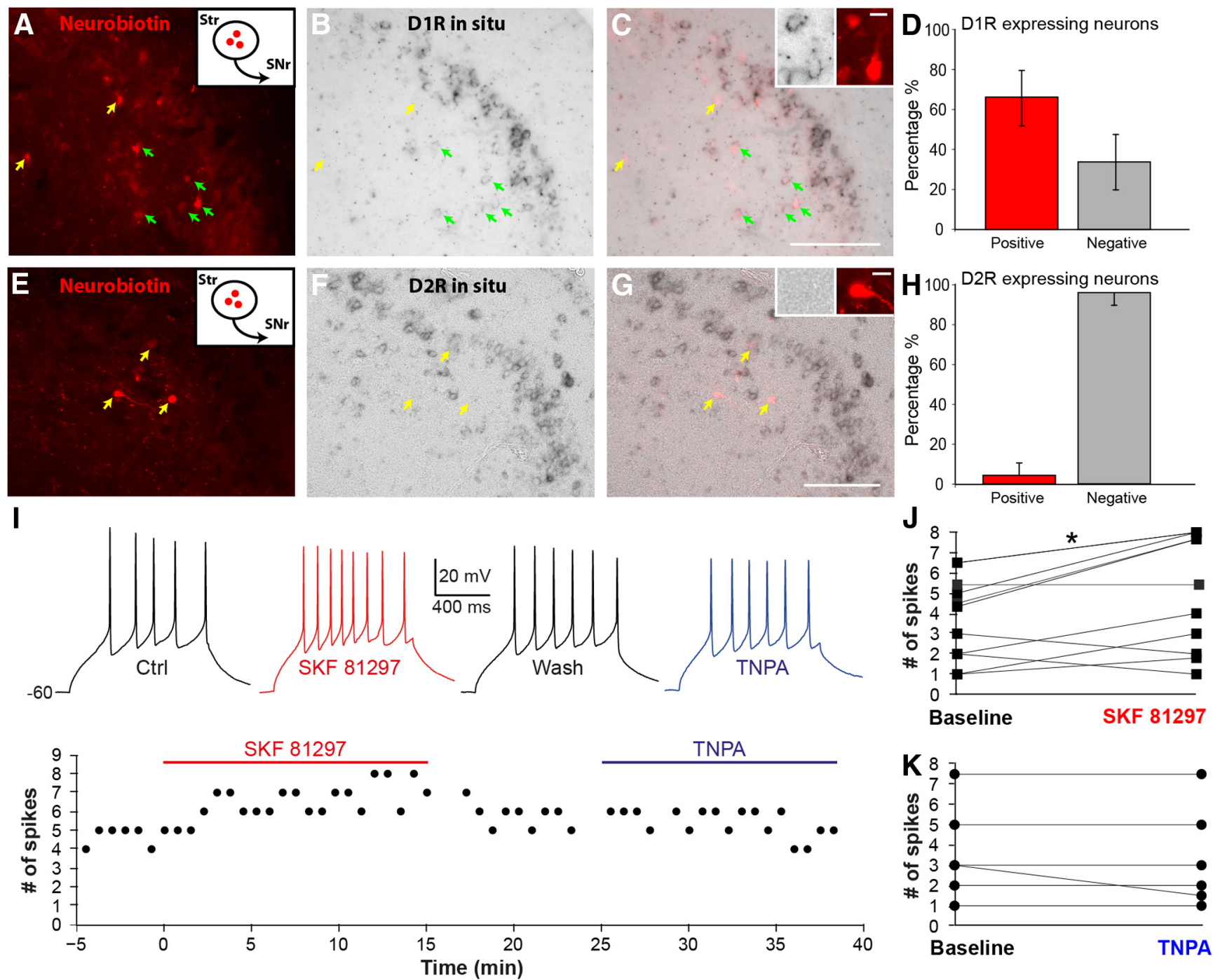

Figure 1. Striatonigral neurons express functional $D_{1}$ receptors that excite neurons. $A$, Striatal neurons (Str) retrogradely labeled after injections of Neurobiotin into the SNr. B, DIG-labeled $D_{1}$ receptor riboprobe expressed in a subpopulation of striatal neurons. $C$, Merged image showing the overlap between retrogradely labeled cells and $D_{1}$ receptor mRNA. Inset shows at higher magnification an example of two cells that are retrogradely labeled and express the $D_{1}$ receptor. Yellow arrows indicate neurons that are retrogradely labeled but do not express $D_{1}$ receptor $m R N A$. Green arrows indicate neurons that are retrogradely labeled and express $D_{1}$ receptor $m R N A$. $D$, Quantification showing the percentage of retrogradely labeled neurons that express $D_{1}$ receptor $m R N A$. $\boldsymbol{E}$, Striatal neurons retrogradely labeled after injections of Neurobiotin into the $\mathrm{SNr}$. $\boldsymbol{F}$, DIG-labeled $\mathrm{D}_{2}$ receptor riboprobe expressed in a subpopulation of striatal neurons. $\mathbf{G}$, Merged image showing the lack of overlap between retrogradely labeled cells and $D_{2}$ receptor $m R N A$. Inset shows at higher magnification an example of one cell that is retrogradely labeled and is devoid of $D_{2}$ receptor expression. Yellow arrows indicate neurons that are retrogradely labeled but do not express $\mathrm{D}_{2}$ receptor $\mathrm{mRNA}$. $\boldsymbol{H}$, Quantification showing the percentage of retrogradely labeled neurons that express $D_{2}$ receptor mRNA. I, Evoked APs in a retrogradely labeled striatonigral neuron during subsequent application of $10 \mu \mathrm{m}$ SKF 81297 (red, 2nd trace and bar below) and $100 \mu \mathrm{m}$ TNPA (blue, last trace and bar below) shown in a corresponding plot of time and the number of spikes evoked by the same near-rheobase current step. This neuron only responded to application of SKF 81297 , which increased spiking seen in the plot, whereas TNPA had no effect on the number of evoked spikes. Ctrl, Control. J, Application of SKF 81297 enhanced evoked spiking in striatonigral neurons, and all but one of the tested neurons were unresponsive to sequential application of TNPA $(\boldsymbol{K}),{ }^{*} p<0.05$. Scale bars, $200 \mu \mathrm{m}$.

the number of evoked spikes a few minutes after bath application. The dopamine $\mathrm{D}_{2}$ receptor activation by TNPA had a distinct effect on the excitability of approximately half of the striatopallidal cells, markedly reducing evoked spikes by $45 \pm 14 \%$ in 7 of 16 cells (Fig. $2 G ; p<0.001$, Wilcoxon's signed-ranks test). In these seven $\mathrm{D}_{2}$ responsive cells, application of SKF 81297 had no overall effect on excitability (Fig. 2F; $p>0.2$, Wilcoxon's signed-ranks test), although one cell was slightly excited and another inhibited by the $\mathrm{D}_{1}$ agonist. The data thus suggest that this subpopulation of striatopallidal neurons preferentially express $\mathrm{D}_{2}$ receptors that suppress spiking activity during activation. These neurons are thus presumably part of the indirect pathway that preferentially targets the GPe-like neurons in the dorsal pallidum.
Another subpopulation of striatopallidal neurons express $D_{1}$ receptors and their activation excites neurons

The results from the $\mathrm{D}_{2}$ receptor expression mapping suggest that the other half of the striatal neurons projecting to the dorsal pallidum should represent the striatal neurons projecting to the GPi-like neurons in the dorsal pallidum and express dopamine $\mathrm{D}_{1}$ receptors (Fig. $3 A-C$ ). Again, as with the $\mathrm{D}_{2}$ receptors, just less than half of the neurons, retrogradely labeled from the dorsal pallidum, colocalized with the in situ hybridization signal for the $\mathrm{D}_{1}$ receptor (Fig. $3 A-D ; 42.2 \pm 3.1 \%, n=2$ ).

To determine whether these neurons selectively respond to $D_{1}$ receptor agonists, both $\mathrm{D}_{1}$ and $\mathrm{D}_{2}$ receptor agonists were sequentially applied during recordings from retrogradely labeled neu- 


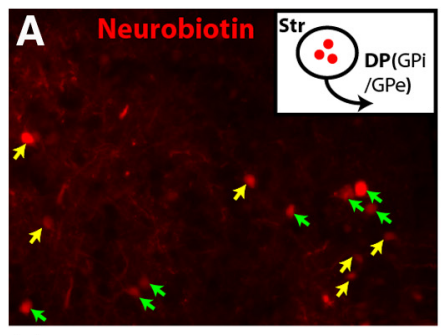

E

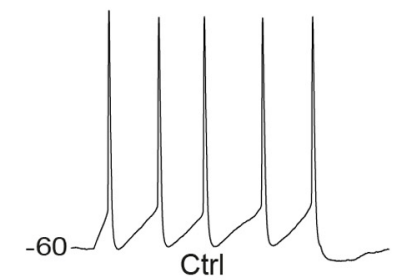

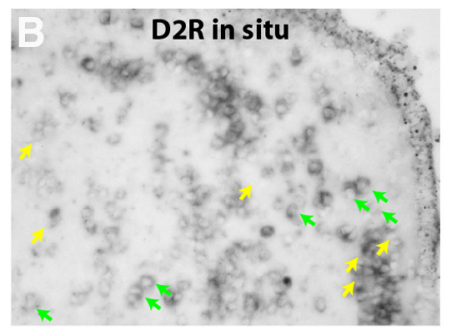

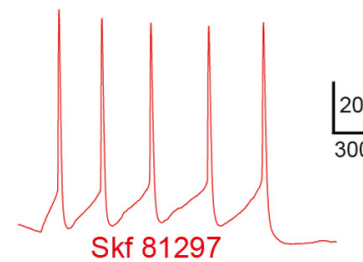

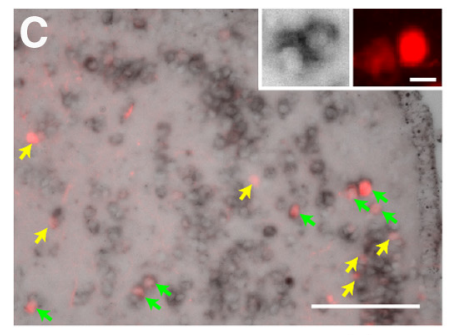

$\mathbf{F}$
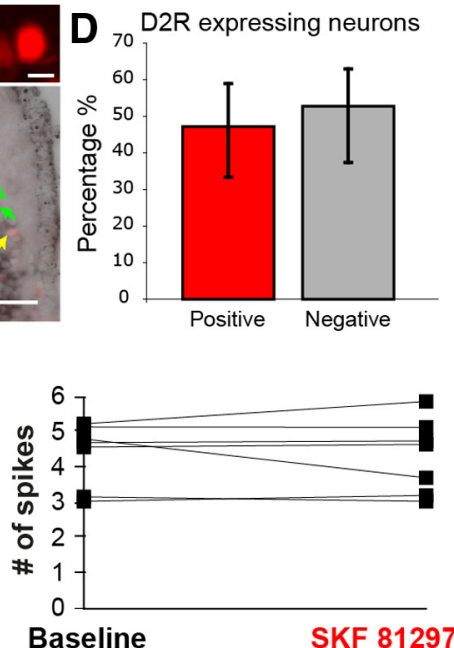

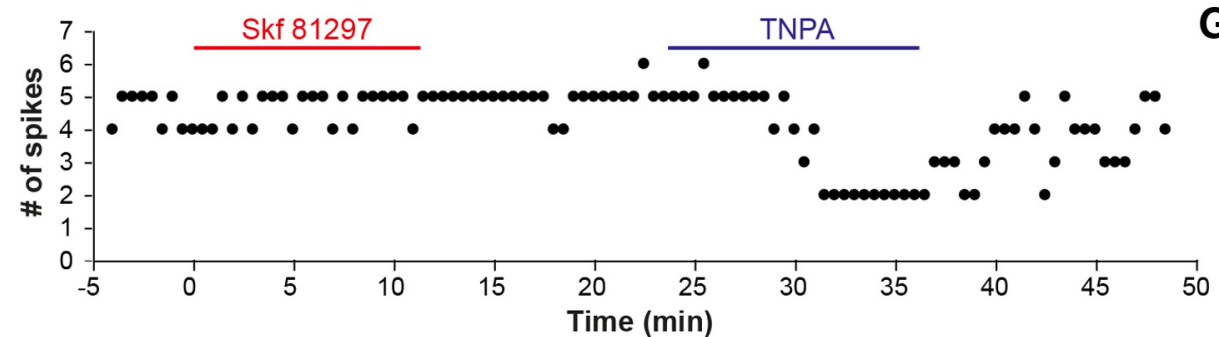

G

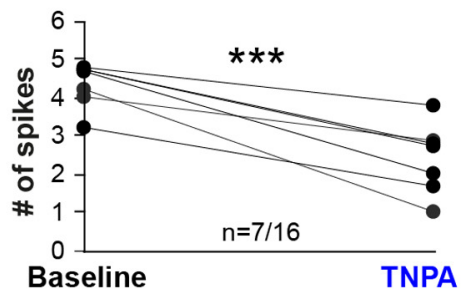

Figure 2. One subgroup of striatopallidal neurons expresses functional $D_{2}$ receptors that reduce excitability. $A$, Striatal neurons retrogradely labeled after injections of Neurobiotin into the dorsal pallidum (DP). $\boldsymbol{B}$, DIG-labeled $\mathrm{D}_{2}$ receptor riboprobe expressed in a subpopulation of striatal neurons. $C$, Merged image showing the overlap between retrogradely labeled cells and $\mathrm{D}_{2}$ receptor $m R \mathrm{R} \mathrm{A}$. Inset shows at higher magnification an example of two cells that are retrogradely labeled and that express the $D_{2}$ receptor. Yellow arrows indicate neurons that are retrogradely labeled express $D_{2}$ receptor mRNA. Green arrows indicate neurons that are retrogradely labeled and express $D_{2}$ receptor mRNA. $\boldsymbol{D}$, Quantification showing the percentage of retrogradely labeled neurons that express $D_{2}$ receptor mRNA. $\boldsymbol{E}$, Evoked APs in a retrogradely labeled striatopallidal neuron during sequential application of $10 \mu \mathrm{m}$ SKF 81297 (red trace and bar) and $100 \mu \mathrm{M}$ TNPA (blue trace and bar). This neuron does not respond to application of SKF 81297, whereas application of TNPA potently reduces the number of evoked spikes. Ctrl, Control. F, Application of SKF 81297 did not significantly affected excitability, although a few of the neurons slightly increased or decreased their spiking. $G$, In these seven cells ( $n=7$ of 16), application of TNPA had a pronounced effect on evoked spikes that were reduced by the $D_{2}$ activation, ${ }^{* *} p<0.001$. Scale bars, $200 \mu \mathrm{m}$.

rons. Figure $3 E$ shows a retrogradely labeled striatopallidal neuron that, in contrast to the previously described striatopallidal subpopulation, was excited by application of SKF 81297 (10 $\mu \mathrm{M}$, red trace and time bar) that increased the evoked discharge. Washout partially reversed the effect of $D_{1}$ activation. Subsequent application of TNPA (100 $\mu \mathrm{M}$, blue trace and time bar) had no effect on the number of evoked spikes, further indicating the existence of two segregated striatopallidal pathways. Application of SKF 81297 increased the excitability of just less than half of the striatopallidal neurons, increasing the number of evoked spikes by an average of $31 \pm 7 \%$ in 6 of 16 cells (Fig. 3F; $p<0.01$, Wilcoxon's signed-ranks test). In five of these six cells, TNPA was subsequently applied without any effect on excitability (Fig. 3G; $p=0.73, t$ test). Furthermore, three neurons did not respond to either SKF 81297 or TNPA (data not shown).

These results suggest that the subpopulations of striatal neurons projecting to the dorsal pallidum differentially express either dopamine $\mathrm{D}_{1}$ or $\mathrm{D}_{2}$ receptors. One group of striatopallidal neurons expresses dopamine $\mathrm{D}_{2}$ receptors and their activation suppresses neuronal output, whereas $\mathrm{D}_{1}$ activation has no effect. The other neuron type instead expresses dopamine $\mathrm{D}_{1}$ receptors that excite neurons during activation, although these neurons are unresponsive to $\mathrm{D}_{2}$ agonists. Because the $\mathrm{D}_{1}$ receptors are colocalized with neurons that express substance $\mathrm{P}$ and project directly to the GPi in mammals, our results suggest that the $\mathrm{D}_{1}$ receptorexpressing subpopulation may be the same as the "directly" projecting substance $\mathrm{P}$ population in lamprey. In contrast, the $\mathrm{D}_{2}$ receptors are likely expressed in the enkephalin population that projects to the GPe neurons in the lamprey dorsal pallidum (Stephenson-Jones et al., 2011). The mammalian organization of $\mathrm{D}_{1}$-expressing neurons projecting to the $\mathrm{GPi}$ and $\mathrm{D}_{2}$-expressing neurons projecting to the GPe may thus be conserved in lamprey, although the GPi and GPe neurons are intermingled in one nucleus, the dorsal pallidum. Together, these results suggest that the organization with striatal neurons of the direct and indirect pathway differentially expressing $D_{1}$ and $D_{2}$ receptors existed already at the dawn of vertebrate evolution.

\section{Cellular effects by $D_{1}$ receptor activation}

To further characterize the changes in excitability induced by dopamine, we pooled the data from the striatonigral neurons and the $\mathrm{D}_{1}$ - but not $\mathrm{D}_{2}$-responsive striatopallidal neurons into a single group termed "direct projection neurons" (Table $1 ; n=20$ ).

In the other vertebrates investigated, the dopaminergic modulation of striatal neurons is dependent on the voltage baseline, in which $D_{1}$ receptor agonists preferentially enhance excitability at membrane potentials close to spike threshold (Hernández-López et al., 1997; Ding and Perkel, 2002; Barral et al., 2010). In patchclamp recordings at a depolarized holding potential (approximately -55 to $-60 \mathrm{mV}$; Fig. $4 A$ ), the direct projecting lamprey striatal neurons were excited by application of the $\mathrm{D}_{1}$ agonist SKF $81297(10 \mu \mathrm{M})$, as seen by the increased number of evoked APs (Fig. $4 A_{1}$ ). The increase in firing was evident throughout a series of current injections (Fig. $4 A_{2}$ ), with an average increase in firing 

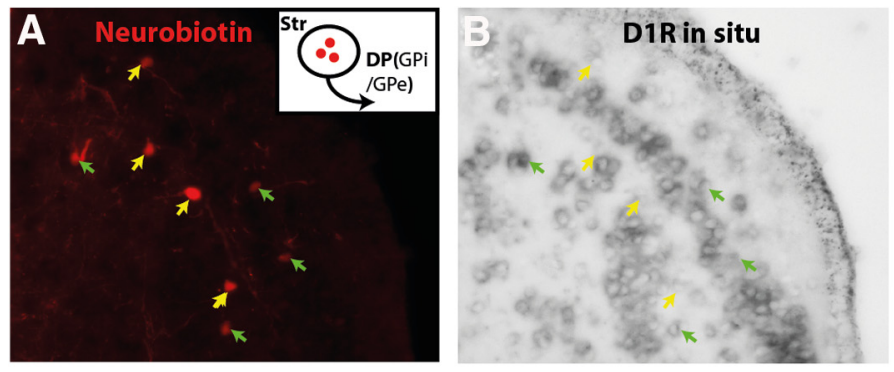

E
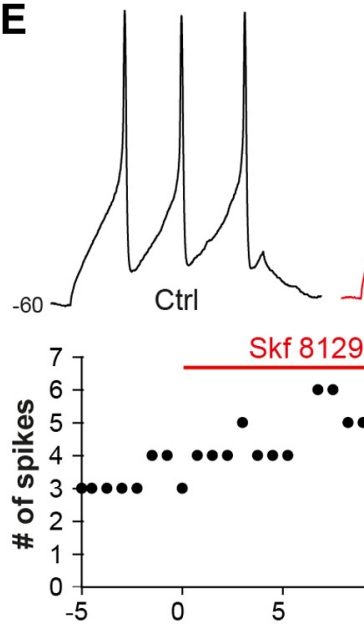

kf 81297
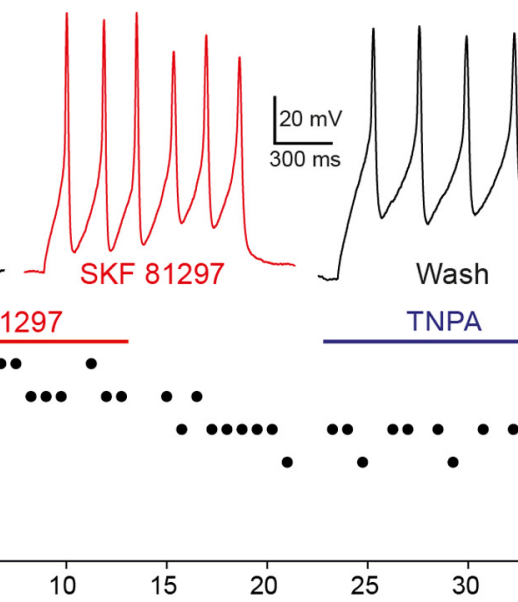

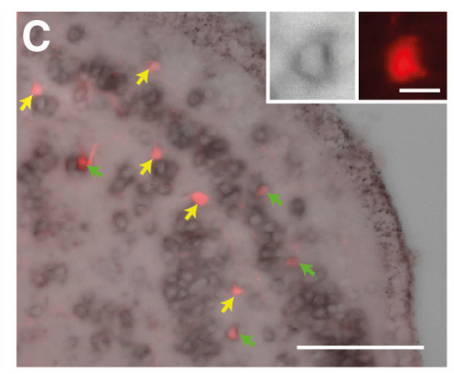

D D1R expressing neurons

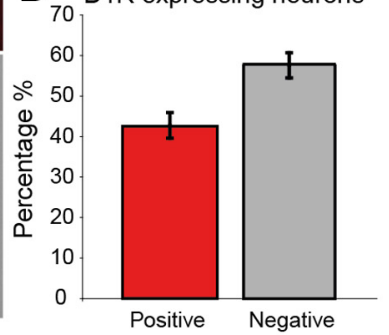

$\mathbf{F}$

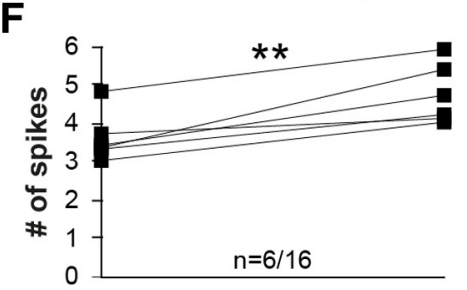

TNPA

G

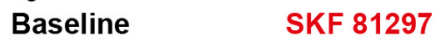

G

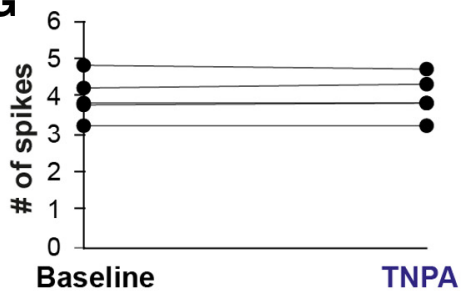

Figure 3. One subgroup of striatopallidal neurons expresses functional $D_{1}$ receptors that enhance excitability. $A$, Striatal neurons retrogradely labeled after injections of Neurobiotin into the dorsal pallidum (DP). B, DIG-labeled D receptor riboprobe expressed in a subpopulation of striatal neurons. $C$, Merged image showing the overlap between retrogradely labeled cells and $D_{1}$ receptor mRNA. Inset shows at higher magnification an example of one cell that is retrogradely labeled and express the $D_{1}$ receptor. Yellow arrows indicate neurons that are retrogradely labeled but do not express $D_{1}$ receptor $m R N A$. Green arrows indicate neurons that are retrogradely labeled and express $D_{1}$ receptor $m R N A$. $D$, Quantification showing the percentage of retrograde labeled neurons that express $\mathrm{D}_{1}$ receptor mRNA. E, Evoked APs in a retrogradely labeled striatopallidal neuron during sequential application of $10 \mu \mathrm{m}$ SKF 81297 (red trace and bar) and $100 \mu \mathrm{m}$ TNPA (blue trace and bar). This neuron responds to application of SKF 81297 by increasing spike discharge, whereas application of TNPA does not affect the number of evoked spikes. Ctrl, Control. $F$, Enhanced spiking by SKF 81297 was seen in 6 of 16 cells, and five of these six cells were unresponsive to TNPA (G), ${ }^{* *} p<0.01$. Scale bars, $200 \mu \mathrm{m}$.

Table 1. Effects of dopamine agonists on intrinsic properties of projection neurons

\begin{tabular}{|c|c|c|c|c|c|c|c|c|}
\hline & \multicolumn{4}{|c|}{ Direct projection neurons } & \multicolumn{4}{|c|}{ Indirect projection neurons } \\
\hline & Baseline & $\begin{array}{l}\text { SKF } 81297 \\
(n=17)\end{array}$ & Pre & $\begin{array}{l}\text { TNPA } \\
\text { (no effect) }\end{array}$ & Baseline & TNPA & Pre & $\begin{array}{l}\text { SKF } 81297 \\
\text { (no effect) }\end{array}$ \\
\hline Resting potential $\left(V_{\mathrm{m}}\right)$ & $-72.3 \pm 2.2^{*}$ & $-71.0 \pm 2.8^{*}$ & & & $-69.6 \pm 4.1$ & $-69.4 \pm 4.7$ & & \\
\hline Amplitude of APs (mV) & $57.4 \pm 2.5^{*}$ & $47.2 \pm 3.4^{*}$ & $53.8 \pm 1.2$ & $52.3 \pm 4.3$ & $49.9 \pm 3.0^{*}$ & $35.0 \pm 3.2^{*}$ & $49.4 \pm 4.7$ & $46.4 \pm 5.3$ \\
\hline Threshold for APs (mV) & $-47.6 \pm 1.6^{*}$ & $-45.8 \pm 1.6^{*}$ & $42.2 \pm 2.1$ & $-42.9 \pm 2.3$ & $-47.2 \pm 2.2^{*}$ & $-40.5 \pm 2.8^{*}$ & $-44.1 \pm 3.1$ & $-43.7 \pm 2.8$ \\
\hline Half-width of single AP (mV) & $5.5 \pm 0.5^{*}$ & $6.0 \pm 0.7^{*}$ & $7.0 \pm 1.2$ & $7.0 \pm 1.4$ & $7.0 \pm 1.1$ & $7.7 \pm 1.1$ & $8.4 \pm 0.7$ & $8.1 \pm 0.8$ \\
\hline Input resistance $(\mathrm{G} \Omega$ ) & $2.2 \pm 0.2$ & $2.3 \pm 0.3$ & $2.8 \pm 0.3$ & $2.8 \pm 0.2$ & $2.6 \pm 0.3$ & $2.8 \pm 0.4$ & $2.8 \pm 0.5$ & $2.7 \pm 0.4$ \\
\hline Amplitude of PIR spike (mV) & $61.6 \pm 7.7^{*}$ & $43.0 \pm 10.5^{*}$ & & & $58.5 \pm 3.4^{*}$ & $38.0 \pm 4.3^{*}$ & & \\
\hline Threshold of PIR spike (mV) & $-59.3 \pm 2.1$ & $-60.1 \pm 2.4$ & & & $-52.0 \pm 3.2^{*}$ & $-43.4 \pm 3.3^{*}$ & & \\
\hline
\end{tabular}

Results expressed as mean \pm SEM. Direct projection neurons, Pooled data from striatonigral and $D_{1}$-responsive striatopallidal neurons; Indirect projection neurons, $D_{2}$-responsive striatopallidal and unlabeled neurons; Pre, regular aCSF before drug application. * indicates significant differences.

frequency of $31 \pm 10 \%\left(n=20, p<0.001, t\right.$ test; Fig. $\left.4 A_{3}\right)$ near-rheobase current injection. In contrast, at a more negative holding potential (approximately $-80 \mathrm{mV}$ ), there was no enhancement in excitability (Fig. $4 B$ ). The number of evoked spikes was on average the same before and after application of SKF 81297 (Fig. $4 B_{1}-B_{3} ; n=13, p>0.2$, Wilcoxon's signed-ranks test).

In four neurons, hyperpolarizing current injections from the depolarized baseline $(-55$ to $-60 \mathrm{mV})$ also evoked PIR APs after the termination of the hyperpolarization (Fig. $4 A_{4}$ ). In these neurons, $D_{1}$ receptor activation also enhanced excitability by increasing the number of PIR spikes (example in Fig. $4 A_{1}$, right trace vs left trace). The spiking increased by $84 \pm 24 \%(n=4, p<0.01, t$ test; Fig. $4 A_{4}$ ), quantified by the total number of PIR spikes evoked by the consecutive hyperpolarization pulses as exemplified in Figure $4 A_{1}$. At this hyperpolarized baseline, three of the four neurons with PIR spikes did not fire any hyperpolarizationactivated APs (Fig. $4 B_{1}, B_{4}$ ), indicating that the currents underlying these spikes have a more depolarized activation range. However, one neuron did still produce PIR spikes, which slightly increased in number during $\mathrm{D}_{1}$ activation (Fig. $4 B_{4}$ ).

In addition to the increased spiking, application of SKF 81297 slightly depolarized half of the neurons $(n=8$ of $20,3.3 \pm 0.3$ $\mathrm{mV}$ ) and clearly affected the properties of APs (summarized in Table 1). The amplitude was reduced from $57.4 \pm 2.5$ to $47.2 \pm$ $3.4 \mathrm{mV}(p<0.001, t$ test $)$, and the threshold shifted to a slightly 

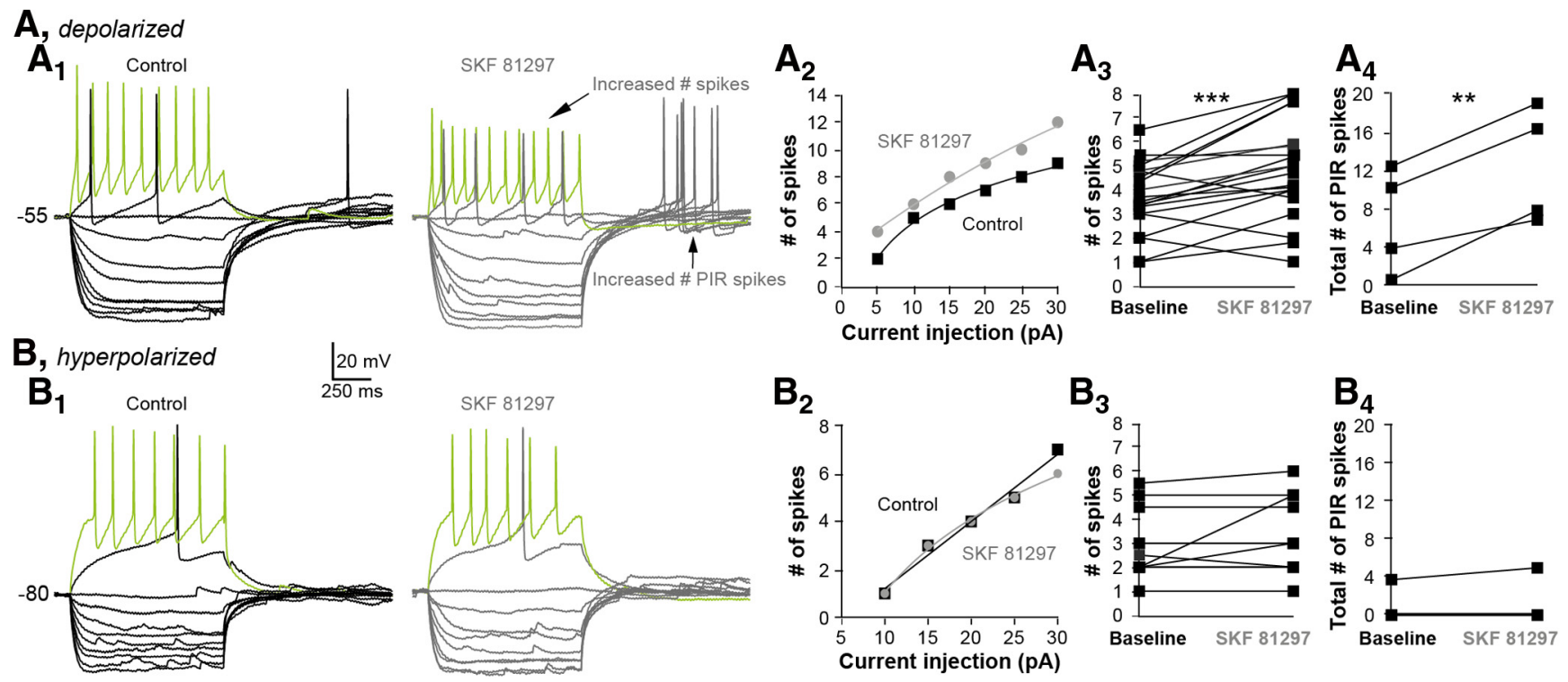

Figure 4. $\quad D_{1}$ receptor activation by the agonist SKF 81297 excites depolarized neurons. $A$, Evoked response patterns of striatal neurons held at depolarized membrane potentials $(-55$ to -65 $\mathrm{mV}$ ). Application of SKF $81297(10 \mu \mathrm{m})$ enhances the firing. $A_{1}$, Voltage responses of a neuron (striatonigral) to hyperpolarizing and depolarizing $1 \mathrm{~s}$ current steps of $5 \mathrm{pA}$ per step, elicited from a depolarized potential at $-55 \mathrm{mV}$ in control aCSF (left, control) or during bath application SKF 81297 (right). SKF 81297 increases the number of evoked spikes (arrow) and PIR spikes (arrow). The hyperpolarizing voltage responses are similar in control and SKF 81297, indicating that there is no change in input resistance. $A_{2}$, Current-frequency diagram of the same neuron showing the increased number of evoked spikes during SKF 81297 (gray circles) compared with control (black squares). $\boldsymbol{A}_{3}$, Application of SKF 81297 increases the number of evoked spikes in $D_{1}$ receptorstimulated neurons, measured near rheobase, ${ }^{* * *} p<0.001$. $A_{4}$, SKF 81297 increased PIR spikes in four neurons capable of producing such hyperpolarization-activated APs, quantified by the total number of PIR spikes in response to $8-10$ consecutive hyperpolarizations from $-100 \mathrm{mV}$ to baseline as in $A_{1},{ }^{* *} p<0.01$. B, Same protocols as in $\boldsymbol{A}$ but at hyperpolarized potentials at approximately $-80 \mathrm{mV} . \boldsymbol{B}_{1}, \boldsymbol{B}_{2}$, SKF 81297 ( $\boldsymbol{B}_{1}$, right traces) has no effect on evoked potentials when they are elicited from $-80 \mathrm{mV}$ compared with control ( $\boldsymbol{B}_{1}$, left traces), and the neuron (same as in $\boldsymbol{A}$ ) does not fire PIR spikes from this negative potential. $\boldsymbol{B}_{3}$, This was consistent for almost all cells tested. $\boldsymbol{B}_{4}$, Only one of the four neurons with PIR spikes at depolarized potentials were capable of producing such APs from hyperpolarized levels.

more depolarized value from $-47.6 \pm 1.6$ to $-45.8 \pm 1.6 \mathrm{mV}$ $(p<0.05, t$ test). The APs also broadened slightly from $5.5 \pm 0.5$ to $6.0 \pm 0.7 \mathrm{~ms}(p<0.05, t$ test). In cells capable of eliciting PIR spikes, the amplitude of these spikes decreased from $61.6 \pm 7.7$ to $43.0 \pm 10.5 \mathrm{mV}(p<0.05, t$ test $)$, and although three of four cells lowered their threshold, the overall shift was not statistically significant (baseline, $-59.3 \pm 2.1$; SKF 81297, $-60.1 \pm 2.4 ; p=$ $0.33, t$ test).

These findings show that, as in mammals (Calabresi et al., 1987; Hernández-López et al., 1997; Surmeier et al., 2007), dopamine $D_{1}$ receptor activation enhances the excitability of striatal neurons at depolarized levels. This suggests that activation of the $D_{1}$ receptor modulates voltage-gated channels that are active at potentials above $-60 \mathrm{mV}$ and that contribute to both PIRs and regular APs.

\section{Reduction of striatal excitability by $D_{2}$ receptor activation}

The detailed cellular responses to $\mathrm{D}_{2}$ receptor activation were also analyzed in all $\mathrm{D}_{2}$-responsive neurons, including seven (of 16) striatopallidal neurons (100 $\mu \mathrm{M}$; Figs. 1,2$)$. In direct contrast to the $D_{1}$ activation, application of TNPA reduced the number of both regularly evoked APs and PIR spikes, in a total of 14 , including nonlabeled and labeled cells (Fig. $5 A_{1}$ ). The reduction was seen throughout consecutive suprathreshold current injections (Fig. $5 A_{2}$ ), and the average spiking frequency decreased by $47 \pm$ $13 \%\left(p<0.001, t\right.$ test, $n=14$; Fig. $\left.5 A_{3}\right)$. As with $\mathrm{D}_{1}$ activation, the amplitude of APs was markedly reduced from $49.9 \pm 3.0$ to $35 \pm 3.2 \mathrm{mV}(p<0.001, t$ test, $n=14$, Table 1$)$, and the threshold for the AP was shifted from $-47.2 \pm 2.2$ to $-40.5 \pm 2.8 \mathrm{mV}$ $(p<0.01, t$ test, $n=14$; Table 1$)$. The number of hyperpolarization-activated APs was also significantly reduced by $84 \pm 49 \%\left(p<0.001, t\right.$ test, $n=8$; Fig. $\left.5 A_{4}\right)$, and their amplitudes were reduced from $58.5 \pm 3.4$ to $38.0 \pm 4.3 \mathrm{mV}(p<$
$0.001, t$ test, $n=6$, Table 1 ). In contrast to $\mathrm{D}_{1}$-responsive neurons, the threshold for PIR spikes was markedly depolarized from $-52.0 \pm 3.2$ to $-43.4 \pm 3.3 \mathrm{mV}(p<0.05$, $t$ test, $n=6$; Table 1$)$. Another contrasting difference from $\mathrm{D}_{1}$-activated neurons was that the decreased excitability was voltage independent, and the reduced discharge persisted at hyperpolarized potentials (approximately $-80 \mathrm{mV})$ during TNPA application $(p<0.01, t$ test, $n=7$; Fig. $5 B_{1}-B_{3}$ ). At this negative potential, very few PIR spikes were evoked even during control conditions (Fig. $5 B_{1}, B_{4}$ ). The same voltage-independent action with $\mathrm{D}_{2}$ receptor agonists has also been observed in birds but not in mammals (HernándezLópez et al., 2000; Ding and Perkel, 2002).

Our results thus show that dopamine $\mathrm{D}_{2}$ receptor activation exerts opposite effects on excitability compared with $\mathrm{D}_{1}$ activation in responsive striatal projection neurons. The distinct separation of enhancing ( $D_{1}$ activation) or reducing ( $D_{2}$ activation) PIR spiking in the subset of striatal neurons capable of producing such APs further emphasizes the difference in dopamine modulation of striatal projection neurons.

\section{Discussion}

Our results suggest that the mechanism by which dopamine modulates the activity of striatal projection neurons is conserved across the vertebrate phylum, together with the intrinsic organization of the basal ganglia. As with mammalian species, the striatal neurons that project directly to the basal ganglia output nuclei predominantly express dopamine $\mathrm{D}_{1}$ receptors, whereas those that project to the dorsal pallidum, the homolog of the GPi/GPe, express either dopamine $D_{1}$ or $D_{2}$ receptors (Fig. 6). Furthermore, activation of these dopamine receptors leads to an increase in the excitability of $\mathrm{D}_{1}$ expressing neurons and a decrease in the excitability of $\mathrm{D}_{2}$ expressing neurons. Together, these results suggest that the 

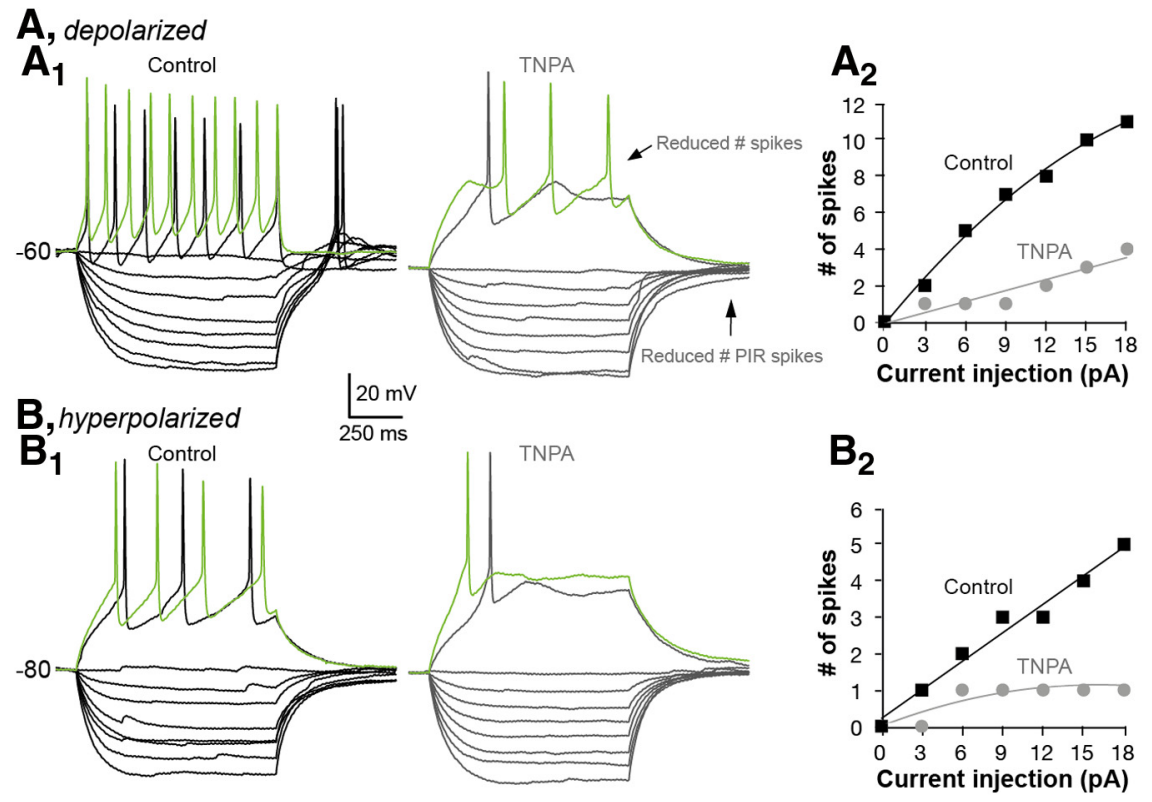
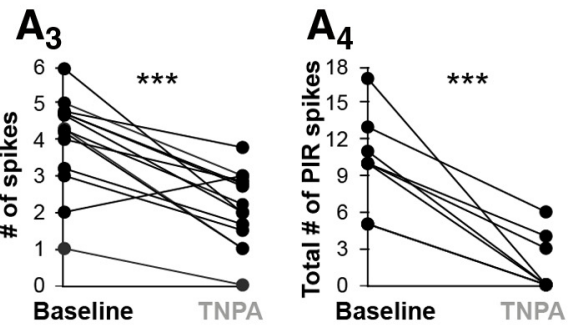

$\mathrm{B}_{3}$
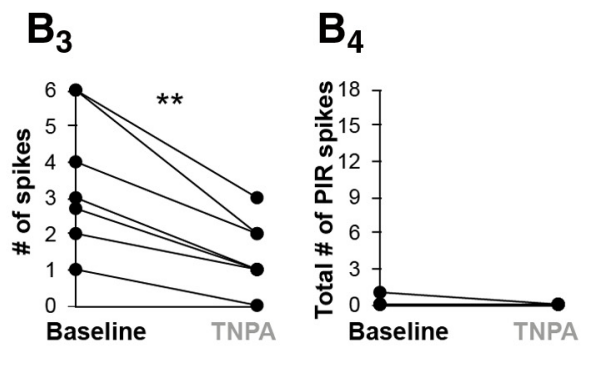

Figure 5. $D_{2}$ receptor activation by the agonist TNPA inhibits neurons. $A$, Evoked response patterns of striatal neurons held at depolarized levels before and during application of TNPA (100 $\mu \mathrm{M}$ ) that reduce excitability. $\boldsymbol{A}_{\boldsymbol{1}}$, Voltage responses of a neuron to hyperpolarizing and depolarizing $1 \mathrm{~s}$ current steps of $3 \mathrm{pA} \mathrm{per} \mathrm{step,} \mathrm{elicited} \mathrm{at} \mathrm{membrane} \mathrm{potentials} \mathrm{at} \mathrm{approximately}-55 \mathrm{mV}$ in control aCSF (left, control) or during bath application TNPA (right). TNPA reduces the number of evoked spikes (arrow) and PIR spikes (arrow). The hyperpolarizing voltage responses are similar in control and TNPA, indicating that there is no change in input resistance. $A_{2}$, Current-frequency diagram of the same neuron showing the decreased number of evoked spikes during TNPA (gray circles) compared with control (black squares). $A_{3}$, Application of TNPA potently reduces the number of evoked spikes in $\mathrm{D}_{2}$-stimulated neurons, measured at near-rheobase positive current injection, ${ }^{* * *} p<0.001$. $A_{4}$, TNPA strongly reduced PIR spikes in all neurons capable of producing such hyperpolarization-activated APs, quantified by the total number of PIR spikes in response to 8 -10 consecutive hyperpolarizations from $-100 \mathrm{mV}$ to baseline as in $\boldsymbol{A}_{1},{ }^{* * *} p<0.001$. $\boldsymbol{B}$, Same protocols as in $\boldsymbol{A}$ but at hyperpolarized potentials at approximately $-80 \mathrm{mV}$. $\boldsymbol{B}_{1}, \boldsymbol{B}_{2}$, TNPA $\left(\boldsymbol{B}_{1}\right.$, right traces) reduces evoked potentials also when they are elicited from a hyperpolarized baseline approximately $-80 \mathrm{mV}$ compared with control ( $\boldsymbol{B}_{1}$, left traces). The neuron (same as in $\boldsymbol{A}$ ) does not fire PIR spikes from this negative potential. $\boldsymbol{B}_{3}$, The reduced spiking was consistent for all cells tested, ${ }^{* *} p<0.01 . \boldsymbol{B}_{4}$, Only one of all neurons with PIR spikes at depolarized potentials were capable of producing such APs from hyperpolarized levels.

A

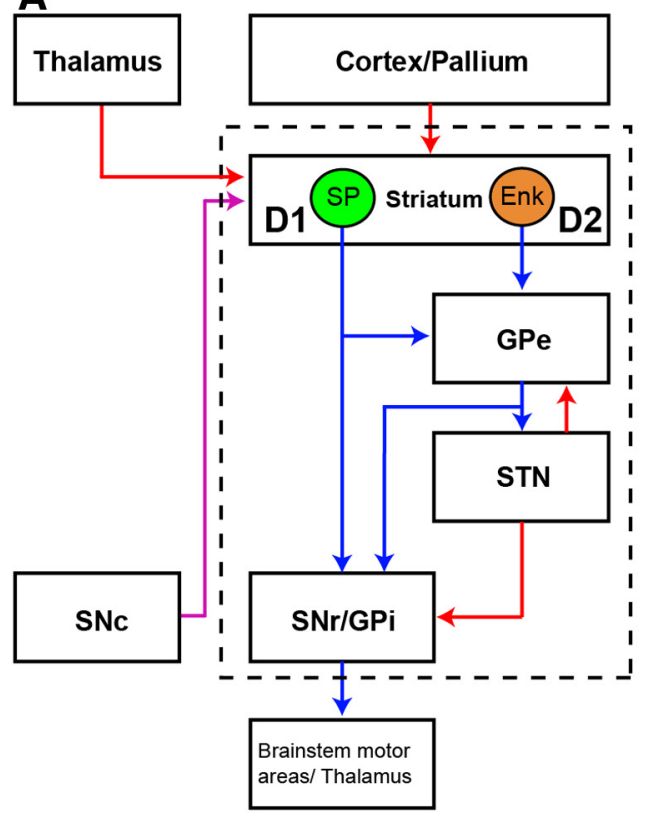

B

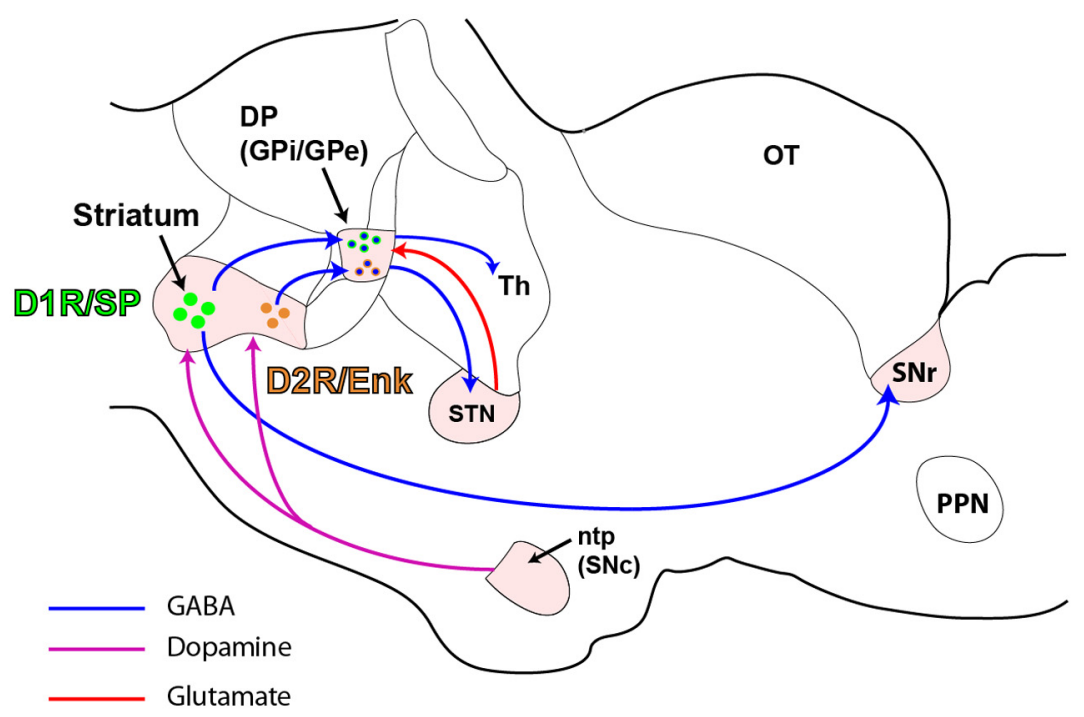

Figure 6. Summary of the organization of the direct and indirect pathways in lamprey. $A$, Schematic drawing showing the evolutionarily conserved architecture of the basal ganglia. Blue, pink, and red arrows indicate GABAergic, dopaminergic, and glutamatergic projections, respectively. $\boldsymbol{B}$, Schematic sagittal section through the lamprey brain showing the location of the known basal ganglia nuclei and the connectivity of the direct and indirect pathways from the striatum to the output nuclei. Enk, Enkephalin; ntp, nucleus tuberculi posterior; $0 \mathrm{~T}, \mathrm{optic}$ tectum; SP, substance P; PPN, pedunculopontine nucleus; Th, thalamus.

dichotomous effect of dopamine on the so-called direct and indirect pathways has been conserved throughout the vertebrate phylum, likely as a mechanism to bias the network toward action selection and facilitate procedural learning.
Dopamine receptor expression in striatal projection neurons Our results suggest that the majority of lamprey striatal neurons express either dopamine $D_{1}$ or $D_{2}$ receptors, although our electrophysiological results indicate that a small proportion of neu- 
rons may express both types of dopamine receptors. This segregation of dopamine receptor expression is also observed in mammals (Gerfen and Surmeier, 2011). In birds, a considerable overlap in the expression of these two dopamine receptors has been suggested (Ding and Perkel, 2002). Analyses of transgenic mice that express GFP under the $\mathrm{D}_{1}$ or $\mathrm{D}_{2}$ receptor promoter have shown that these receptors are segregated, with direct and indirect SPNs expressing $\mathrm{D}_{1}$ or $\mathrm{D}_{2}$ receptors, respectively (Gertler et al., 2008). In situ hybridization studies have further confirmed that $D_{1}$ receptors and substance $P$ are coexpressed in direct pathway SPNs, whereas $\mathrm{D}_{2}$ receptors and enkephalin are coexpressed in indirect projecting SPNs (Le Moine and Bloch, 1995; Gerfen and Surmeier, 2011). In contrast to the anatomical data, electrophysiological experiments in mammals, birds, and indeed in the current study have shown that both $\mathrm{D}_{1}$ and $\mathrm{D}_{2}$ receptor agonists affect the excitability of a limited number of striatal neurons (White and Wang, 1986; Ding and Perkel, 2002). These electrophysiological experiments suggested that some striatal neurons may coexpress $D_{1}$ and $\mathrm{D}_{2}$ receptors, although the anatomical experiments in mammals and our study suggest that this is unlikely. Two alternative explanations have been proposed to reconcile these data. The first is that the dopamine receptor agonists used may be unspecific, and the effect on excitability may be through activation of additional dopamine receptors, including $\mathrm{D}_{3}, \mathrm{D}_{4}$, and $\mathrm{D}_{5}$ receptors. This is possible because, although single-cell RT-PCR studies have shown that $\mathrm{D}_{1}$ and $\mathrm{D}_{2}$ receptors are primarily segregated, they have also shown that direct projecting SPNs coexpress $\mathrm{D}_{3}$ receptors $\left(\mathrm{D}_{2}\right.$-like receptor $)$ and some indirectly projecting SPNs coexpress $\mathrm{D}_{5}$ receptors $\left(\mathrm{D}_{1}\right.$-like receptor) (Surmeier et al., 1996). Furthermore, studies that have used nonspecific $\mathrm{D}_{2}$ receptor family agonists have suggested that there is a larger degree of receptor overlap than those that have used a $\mathrm{D}_{2}$ specific agonist as we have in this study (White and Wang, 1986; Ding and Perkel, 2002). This suggests that part of the electrophysiological results may be explained by coexpression of $D_{1}$ and $D_{2}$ receptors with additional dopamine receptors. It should also be noted that even in studies that have examined the direct effect of dopamine, instead of agonists, the excitability of direct projecting SPNs is increased and the excitability of indirect projecting SPNs are decreased by the application of dopamine (Ding and Perkel, 2002; Planert et al., 2013), suggesting that dopamine still dichotomously influences the excitability of the direct and indirect pathways even if they coexpress additional dopamine receptors.

Another interpretation is that the effect on excitability may be mediated via striatal interneurons that express dopamine receptors (Gerfen and Surmeier, 2011). In mammals, cholinergic as well as parvalbumin- and somatostatin-expressing GABAergic interneurons express dopamine receptors (Yan and Surmeier, 1997; Yan et al., 1997, Centonze et al., 2002, 2003) and contribute to the regulation of the direct and indirect projecting SPNs (Gerfen and Surmeier 2011). Cholinergic neurons have also been observed in the lamprey striatum (Pombal et al., 2001), as have neurons with the physiological hallmarks of fast-spiking parvalbumin-expressing neurons (Ericsson et al., 2011). Whether these interneurons also express dopamine receptors and contribute to the excitability differences we observe in lamprey remains to be determined.

\section{Ionic mechanisms}

Although the general effects of dopamine on the excitability of striatal projection neurons are observed in all vertebrates studied (mammals, turtles, birds, and lamprey), some of the voltagedependent effects reported in the mammalian literature have not been observed in non-mammalian species. In mammals, $\mathrm{D}_{1}$ receptor agonists decrease the excitability of striatal neurons at hyperpolarized potentials (approximately $-80 \mathrm{mV}$ ). In contrast, in our results, as with studies in birds, dopamine $D_{1}$ receptor agonists had no effect on the excitability of striatal neurons at hyperpolarized potentials. In addition in mammals, the $\mathrm{D}_{2}$ effect on excitability was predicted to be dependent on voltage (Hernández-López et al., 2000) because of its action on voltagedependent L-type calcium channels. However, in our study and in birds, the $\mathrm{D}_{2}$ effect on excitability was voltage independent.

Although $\mathrm{D}_{2}$ agonists induce a voltage-independent response in lamprey, their effect on excitability is still likely to be mediated in part through low-voltage-activated L-type calcium channels. In mammals as well as reptiles, $\mathrm{D}_{1}$ and $\mathrm{D}_{2}$ agonists exert opposing effects on L-type calcium channels, increasing and decreasing the L-type calcium current, respectively (HernándezLópez et al., 1997, 2000; Barral et al., 2010). In the lamprey spinal cord, these calcium currents contribute to the generation of the PIR potentials in spinal neurons that are potently suppressed by $\mathrm{D}_{2}$ agonists by reducing the L-type calcium currents (Wang et al., 2011). This suggests that the potent increase ( $D_{1}$ activation) and decrease $\left(D_{2}\right.$ activation) of PIR spikes may be primarily attributable to modulation of the L-type calcium currents in lamprey striatal neurons. In addition, some lamprey striatal neurons express $I_{\mathrm{h}}$, which would also contributes to the PIR (Ericsson et al., 2011), and may be modulated by dopamine. Because both the amplitude and threshold for APs are reduced by $D_{1}$ and $D_{2}$ agonists in lamprey, our results also suggest that the activation of the dopamine receptors influences the activation/inactivation and conductance of voltage-gated $\mathrm{Na}^{+}$channels as they do in mammals (Schiffmann et al., 1995; Maurice et al., 2004; Gerfen and Surmeier, 2011). The $\mathrm{D}_{1}$ modulation of $\mathrm{Na}^{+}$channels likely involves a protein kinase A-dependent phosphorylation that promotes slow inactivation of sodium channels, thereby reducing the number of available $\mathrm{Na}^{+}$channels and decreasing the corresponding conductance (Carr et al., 2003). Because the AP threshold during $\mathrm{D}_{1}$ receptor activation was only reduced at depolarized potentials, this indicates that the effects are voltage dependent as in mammals (Carr et al., 2003; Surmeier et al., 2007) and may be important for reducing spiking when cells are depolarized for prolonged periods.

Finally, in mammals, $\mathrm{D}_{2}$ receptors modulates the activity of the inwardly rectifying potassium channels (Cazorla et al., 2012). These channels also contribute to the resting membrane potential and input resistance. Because we did not observe any changes in the input resistance or in the resting membrane potential of indirect projecting striatal neurons, our results suggest that these channels do not contribute to the dopamine receptor-induced changes in excitability in lamprey. Although not explicitly tested, our results suggest that, as with mammals, the changes in neuronal excitability induced by $D_{1}$ and $D_{2}$ receptor activation may be mediated through differential modulation of L-type calcium currents and through a decrease in sodium conductances.

In mammals, phasic dopamine release not only affects the excitability of striatal neurons but also influences long-term plasticity at the corticostriatal synapses (Bergman et al., 2004). Phasic release of dopamine can promote LTP at the corticostriatal synapses of the direct pathway and LTD at the corticostriatal synapses of the indirect pathway because of the differential expression of $D_{1}$ and $D_{2}$ receptors (Gerfen and Surmeier, 2011). Because direct glutamatergic pallial (cortical)-striatal synapses are also present in lamprey with the same synaptic dynamics as those seen in mammals (Ericsson et al., 2013), dopamine may also modulate the efficacy of these synapses in lamprey, although this needs to be tested explicitly in future studies. 


\section{Conclusion}

Previous studies have shown that the intrinsic organization of the basal ganglia, including all components of the so-called direct and indirect pathways, are present in lamprey and have been conserved throughout the vertebrate phylum as a common mechanism for action selection (Pombal et al., 1997a,b; Ménard and Grillner, 2008; Ericsson et al., 2011; Stephenson-Jones et al., 2011, 2012; Robertson et al., 2012). The results presented here show that the segregated expression of dopamine $\mathrm{D}_{1}$ and $\mathrm{D}_{2}$ receptors in the direct and indirect pathways is also present in the phylogenetically oldest vertebrates, suggesting that this organization also forms a crucial part of the blueprint for the basal ganglia. Because dopamine receptor agonists differentially modulate these pathways, increasing the excitability of the direct pathway that facilitates movement and decreasing the excitability of the indirect pathway that inhibit movements, this organization may be conserved as a mechanism to bias the basal ganglia networks toward action selection.

\section{References}

Albin RL, Young AB, Penney JB (1989) The functional anatomy of basal ganglia disorders. Trends Neurosci 12:366-375. CrossRef Medline

Barbeau A, Dallaire L, Buu NT, Veilleux F, Boyer H, de Lanney LE, Irwin I, Langston EB, Langston JW (1985) New amphibian models for the study of 1-methyl-4-phenyl-1,2,3,6-tetrahydropyridine (MPTP). Life Sci 36: 1125-1134. CrossRef Medline

Barral J, Galarraga E, Tapia D, Flores-Barrera E, Reyes A, Bargas J (2010) Dopaminergic modulation of spiny neurons in the turtle striatum. Cell Mol Neurobiol 30:743-750. CrossRef Medline

Bergman H, Kimura M, Wickens J (2004) Modulation of striatal circuits by dopamine and acetylcholine. In: Microcircuits-the interface between neurons and global brain function (Grillner S, Graybiel A, eds), pp 149162. Cambridge, MA: Massachusetts Institute of Technology.

Calabresi P, Mercuri N, Stanzione P, Stefani A, Bernardi G (1987) Intracellular studies on the dopamine-induced firing inhibition of neostriatal neurons in vitro: evidence for D1 receptor involvement. Neuroscience 20:757-771. CrossRef Medline

Carr DB, Day M, Cantrell AR, Held J, Scheuer T, Catterall WA, Surmeier DJ (2003) Transmitter modulation of slow, activity-dependent alterations in sodium channel availability endows neurons with a novel form of cellular plasticity. Neuron 39:793-806. CrossRef Medline

Cazorla M, Shegda M, Ramesh B, Harrison NL, Kellendonk C (2012) Striatal $D_{2}$ receptors regulate dendritic morphology of medium spiny neurons via Kir2 channels. J Neurosci 32:2398-2409. CrossRef Medline

Centonze D, Bracci E, Pisani A, Gubellini P, Bernardi G, Calabresi P (2002) Activation of dopamine D1-like receptors excites LTS interneurons of the striatum. Eur J Neurosci 15:2049-2052. CrossRef Medline

Centonze D, Grande C, Usiello A, Gubellini P, Erbs E, Martin AB, Pisani A, Tognazzi N, Bernardi G, Moratalla R, Borrelli E, Calabresi P (2003) Receptor subtypes involved in the presynaptic and postsynaptic actions of dopamine on striatal interneurons. J Neurosci 23:6245-6254. Medline

Chu J, Wilczynski W, Wilcox RE (2001) Pharmacological characterization of the D1- and D2-like dopamine receptors from the brain of the leopard frog, Rana pipiens. Brain Behav Evol 57:328-342. CrossRef Medline

Ding L, Perkel DJ (2002) Dopamine modulates excitability of spiny neurons in the avian basal ganglia. J Neurosci 22:5210-5218. Medline

Ericsson J, Silberberg G, Robertson B, Wikström MA, Grillner S (2011) Striatal cellular properties conserved from lampreys to mammals. J Physiol 589:2979-2992. CrossRef Medline

Ericsson J, Stephenson-Jones M, Kardamakis A, Robertson B, Silberberg G, Grillner S (2013) Evolutionary conserved differences in pallial and thalamic short-term synaptic plasticity in striatum. J Physiol 591:859-874. CrossRef Medline

Gerfen CR, Surmeier DJ (2011) Modulation of striatal projection systems by dopamine. Annu Rev Neurosci 34:441-466. CrossRef Medline

Gertler TS, Chan CS, Surmeier DJ (2008) Dichotomous anatomical properties of adult striatal medium spiny neurons. J Neurosci 28:10814-10824. CrossRef Medline

Hernández-López S, Bargas J, Surmeier DJ, Reyes A, Galarraga E (1997) $D_{1}$ receptor activation enhances evoked discharge in neostriatal medium spiny neurons by modulating an L-type $\mathrm{Ca}^{2+}$ conductance. J Neurosci 17:3334-3342. Medline

Hernandez-Lopez S, Tkatch T, Perez-Garci E, Galarraga E, Bargas J, Hamm $\mathrm{H}$, Surmeier DJ (2000) $\mathrm{D}_{2}$ dopamine receptors in striatal medium spiny neurons reduce L-type $\mathrm{Ca}^{2+}$ currents and excitability via a novel PLC $\beta 1-$ IP3-calcineurin signaling cascade. J Neurosci 20:8987-8995. Medline

Le Moine C, Bloch B (1995) D1 and D2 dopamine receptor gene expression in the rat striatum: sensitive cRNA probes demonstrate prominent segregation of D1 and D2 mRNAs in distinct neuronal populations of the dorsal and ventral striatum. J Comp Neurol 355:418-426. CrossRef Medline

Maurice N, Mercer J, Chan CS, Hernandez-Lopez S, Held J, Tkatch T, Surmeier DJ (2004) $\mathrm{D}_{2}$ dopamine receptor-mediated modulation of voltage-dependent $\mathrm{Na}^{+}$channels reduces autonomous activity in striatal cholinergic interneurons. J Neurosci 24:10289-10301. CrossRef Medline

Ménard A, Grillner S (2008) Diencephalic locomotor region in the lamprey—afferents and efferent control. J Neurophysiol 100:1343-1353. CrossRef Medline

Planert H, Berger TK, Silberberg G (2013) Membrane properties of striatal direct and indirect pathway neurons in mouse and rat slices and their modulation by dopamine. PloS One 8:e57054. CrossRef Medline

Pollard HB, Dhariwal K, Adeyemo OM, Markey CJ, Caohuy H, Levine M, Markey S, Youdim MB (1992) A parkinsonian syndrome induced in the goldfish by the neurotoxin MPTP. FASEB J 6:3108-3116. Medline

Pombal MA, El Manira A, Grillner S (1997a) Organization of the lamprey striatum-transmitters and projections. Brain Res 766:249-254. CrossRef Medline

Pombal MA, El Manira A, Grillner S (1997b) Afferents of the lamprey striatum with special reference to the dopaminergic system: a combined tracing and immunohistochemical study. J Comp Neurol 386:71-91. CrossRef Medline

Pombal MA, Marín O, González A (2001) Distribution of choline acetyltransferase-immunoreactive structures in the lamprey brain. J Comp Neurol 431:105-126. CrossRef Medline

Pombal MA, Moussa CE, Sidhu A, Vernier P (2007) Distribution of the dopamine $\mathrm{D}_{1}$ receptor in the lamprey brain: evolutionary implications. Soc Neurosci Abstr 33:351.29.

Redgrave P, Prescott TJ, Gurney K (1999) The basal ganglia: a vertebrate solution to the selection problem? Neuroscience 89:1009-1023. CrossRef Medline

Reiner A, Medina L, Veenman CL (1998) Structural and functional evolution of the basal ganglia in vertebrates. Brain Res Rev 28:235-285. CrossRef Medline

Robertson B, Huerta-Ocampo I, Ericsson J, Stephenson-Jones M, PérezFernández J, Bolam JP, Diaz-Heijtz R, Grillner S (2012) The dopamine D2 receptor gene in lamprey, its expression in the striatum and cellular effects of D2 receptor activation. PLoS One 7:e35642. CrossRef Medline

Schiffmann SN, Lledo PM, Vincent JD (1995) Dopamine D1 receptor modulates the voltage-gated sodium current in rat striatal neurones through a protein kinase A. J Physiol 483:95-107. Medline

Stephenson-Jones M, Samuelsson E, Ericsson J, Robertson B, Grillner S (2011) Evolutionary conservation of the basal ganglia as a common vertebrate mechanism for action selection. Curr Biol 21:1081-1091. CrossRef Medline

Stephenson-Jones M, Ericsson J, Robertson B, Grillner S (2012) Evolution of the basal ganglia; dual output pathways conserved throughout vertebrate phylogeny. J Comp Neurol 520:2957-2973. CrossRef Medline

Surmeier DJ, Song WJ, Yan Z (1996) Coordinated expression of dopamine receptors in neostriatal medium spiny neurons. J Neurosci 16:6579-6591. Medline

Surmeier DJ, Ding J, Day M, Wang Z, Shen W (2007) D1 and D2 dopaminereceptor modulation of striatal glutamatergic signaling in striatal medium spiny neurons. Trends Neurosci 30:228-235. CrossRef Medline

Thompson RH, Ménard A, Pombal M, Grillner S (2008) Forebrain dopamine depletion impairs motor behavior in lamprey. Eur J Neurosci 27: 1452-1460. CrossRef Medline

Wang D, Grillner S, Wallén P (2011) 5-HT and dopamine modulates $\mathrm{CaV} 1.3$ calcium channels involved in postinhibitory rebound in the spinal network for locomotion in lamprey. J Neurophysiol 105:1212-1224. CrossRef Medline

White FJ, Wang RY (1986) Electrophysiological evidence for the existence 
of both D-1 and D-2 dopamine receptors in the rat nucleus accumbens. J Neurosci 6:274-280. Medline

Yanai J, Silverman WF, Shamir D (1995) An avian model for the reversal of 6-hydroxydopamine induced rotating behaviour by neural grafting. Neurosci Lett 187:153-156. CrossRef Medline

Yan Z, Surmeier DJ (1997) D5 dopamine receptors enhance $\mathrm{Zn}^{2+}$-sensitive
GABA(A) currents in striatal cholinergic interneurons through a PKA/ PP1 cascade. Neuron 19:1115-1126. CrossRef Medline

Yan Z, Song WJ, Surmeier J (1997) D2 dopamine receptors reduce N-type $\mathrm{Ca}^{2+}$ currents in rat neostriatal cholinergic interneurons through a membrane-delimited, protein-kinase-C-insensitive pathway. J Neurophysiol 77:1003-1015. Medline 